\title{
Mapping in the Oiapoque Indigenous Territories
}

Community appropriation for local land management

Cartographie dans les territoires amérindiens du Oiapoque : appropriation locale et gestion territoriale par les communautés

\section{Rosélis Remor de Souza Mazurek}

\section{OpenEdition}

\section{Journals}

Electronic version

URL: http://journals.openedition.org/ethnoecologie/2701

DOI: 10.4000/ethnoecologie. 2701

ISSN: 2267-2419

Publisher

Laboratoire Eco-anthropologie et Ethnobiologie

Electronic reference

Rosélis Remor de Souza Mazurek, « Mapping in the Oiapoque Indigenous Territories », Revue

d'ethnoécologie [Online], 9 | 2016, Online since 01 July 2016, connection on 20 April 2019. URL : http:// journals.openedition.org/ethnoecologie/2701 ; DOI : 10.4000/ethnoecologie.2701

This text was automatically generated on 20 April 2019

\section{cc) (†)}

Revue d'ethnoécologie est mis à disposition selon les termes de la licence Creative Commons Attribution - Pas d'Utilisation Commerciale - Pas de Modification 4.0 International. 


\title{
Mapping in the Oiapoque Indigenous Territories
}

\author{
Community appropriation for local land management \\ Cartographie dans les territoires amérindiens du Oiapoque : appropriation locale \\ et gestion territoriale par les communautés
}

Rosélis Remor de Souza Mazurek

\section{Introduction}

1 Participatory mapping is a diverse field encompassing a wide variety of facilitation approaches and cartographic methods that involve local people, empowering them to generate maps that graphically reflect their perceptions of the landscapes where they live (Chambers 2006). Indigenous mapping as a tool for supporting political strategies for traditional land claims and negotiating indigenous rights with governments has been used in the nineteen fifties particularly in Canada and Alaska (Eliana et al. 1985, Chapin et al. 2005). Elsewhere, the use of participatory mapping has been a more recent event linked to indigenous political empowerment and resulting changes in legislation recognizing indigenous and other minority groups rights and providing increased autonomy to manage their natural resources territories (Allegretti 1994, Arias 2003, Herlihy \& Knapp 2003, Cronketon et al. 2010).

In Amazonia the description of sketch mapping by Indigenous Peoples to represent their knowledge about the landscape is already present in the traveling narratives of the ethnologist T. Koch-Grünberg among the Taurepang Indians in the Brazilian State of Roraima in 1911(Koch-Grünberg 1982). More recently mapping by indigenous people in Amazonia has been used to give visibility to the cultural identity linked to the territory and to challenge commonly held views of indigenous lands as « empty spaces » deprived of meaning in the official maps, for territorial planning and natural resource management, to document local history, to describe the geographical transmission 
patterns of traditional ecological knowledge (TEK) (Robert et al. 2006, Akarib 2007, Apiwtxa 2007, Goulart \& Barreto 2011, Povo Manoki 2012, Apolinário 2012, do Vale et al. 2012, Molo \& Zent 2012, Neff \& Ortiz 2012, Fleury et al. 2016).

3 The Article 231 of the Brazilian Constitution (Brasil 1988) states that Indigenous peoples have primary, inherent and unalterable rights to their lands they permanently inhabit and use for productive activity, preservation of natural resources and cultural and spiritual well-being. Indigenous lands are the property of the State; however, the regularization process recognizes and formalizes indigenous rights and specifically guarantees perpetual usufruct by Indigenous Peoples of their lands (Roldán Ortega 2004). Currently there are 700 Indigenous Territories (IT) (« Terras Indígenas » in Portuguese) in Brazil comprising 1,172,995.5 $\mathrm{km}^{2}$ most of them located in Amazonia (422 ITs 1,114,012.07 $\mathrm{km}^{2}$ ) (Instituto Socioambiental 2016). Indigenous participatory mapping is an important component of the anthropological studies that form the basis for IT official demarcation process $^{1}$ (FUNAI 2002, PPTAL 2004). Territorial and resource use management and protection planning in Indigenous Territories has increased in priority for indigenous people as they face increasing threats posed by deforestation, illegal extraction of natural resources and social environmental impacts associated to government infrastructure projects, particularly in Amazonia (Carneiro 2009, Albert et al. 2011, Kahwage \& Marinho 2011).

4 In this paper the focus is on the ITs of Oiapoque-Uaçá, Galibi and Juminã-located in Eastern Amazonia at the Brazilian border with French Guiana where different participatory mapping exercises have been carried out over time using different methods. After sketching the Brazilian context to participatory mapping, the 2001-2003 exercise will be briefly described. It was conducted to strengthen the public recognition of the rights of a complex territorial and multi-ethnic unit. The map was to be used as a political tool in a context of external threats posed to indigenous territorial integrity particularly by government infrastructure projects (e.g. the Highway to French Guiana). The second exercise, carried out between 2013 and 2014, is described in more detail and focused on the dialogue among the indigenous community members from different villages and partner institutions putting efforts to think together about the current territorial use practices as well as on management actions and discussing ways of implementing them. The forms of appropriation of the mapping tool by the Indigenous Peoples in both exercises are discussed.

\section{Participatory mapping of indigenous lands in the brazilian Amazon, northern Amapá State}

5 In Brasil, the mapping of natural resources in indigenous lands has often been done with the objective of territorial claims and natural resources management. ITs are often characterized by low population density, particularly in Amazonia and thus prone to threats (e.g. invasion, illegal extraction) and their borders tend to be poorly enforced by the state.

6 One frequently used technique are sketch maps made in the village (Corbett et al. 2006), which are drawn from observation or memory on large pieces of paper to represent features in the landscape not relying on exact scales. More commonly these days maps are drawn over georeferenced Landsat satellite images and a landscape typology, 
resources and socio-cultural features recognized by the Indigenous Peoples are represented (Trancoso et al. 2012).

7 In Brazil, in several instances the maps were produced by a selected group of young indigenous representatives, generally bilingual and confortable in both cultures (indigenous community and national society), who had received training by NGOs to work as Indigenous Environmental Agents (IEA). In 1996, before participatory mapping, the IEAs appeared in the Indigenous Territories in the State of Acre, adjoining the border with Peru, where young indigenous individuals were trained by the in NGO Pro Indian Commission in agroforestry techniques through capacity building (Gavazzi 2012). Their duties were to work as «multipliers » by carrying out and promoting discussions on territorial and resource management and conservation actions among villages within the ITs. The goal was minimize dependence and improve services provided by government agencies, and most importantly, transmit acquired practices and knowledge to other village members thus increasing community engagement on the same issues.

Indigenous people from Uaçá, Galibi and Juminã ITs of northeastern Amazonia have been discussing land and resource use and management issues with partner NGOs and FUNAI since 2001 as part of the construction of a broader local sustainable development agenda. The results were compiled in an important document denominated The Life Plan of the Indigenous Peoples of Oiapoque (APIO 2009). It contains a summary of the priority actions to improve health services, education, local governance, the protection of territorial integrity, as well as resource use and management and is intended to guide government policies and financial support to the indigenous lands.

Participatory mapping was part of the innovative agenda and it was carried out by IEAs with the financial and technical support of the environmental NGO The Nature Conservancy (TNC 2006) in partnership with the indigenous organization Associação dos Povos Indígenas do Oiapoque (APIO) between 2001and 2003. In Oiapoque, the map was conceived as a tool to fill the « empty spaces » associated to the Indigenous Territories in the official maps; to be use as didactic material in the indigenous schools and support large scale land use and resource management planning in a context of local growing threats posed by illegal resource extraction, infrastructure projects and a growing indigenous population living in a finite territory. The methodology used georeferenced LANDSAT satellite images which formed the background on which the Indigenous Peoples identified and traced (on paper, over the image) culturally relevant elements associated with the landscape. The map was then finalized by TNC technical staff using Arc GIS. The result was a detailed map with multiple layers of information including relief, hydrology, phytogeography, the local landscape typology, toponyms (in Palikur, Patoá and Portuguese, the three languages spoken in the ITs), and historical and mythologically important sites). The map also shows the spatial and temporal variation of natural resources and subsistence activities over the territory, as well as highlighting areas vulnerable to invasion by outsiders and of government development projects with a high potential of negative impact on the ITs. In the regional and national context, the final map $^{2}$ was used by indigenous representatives primarily as a political tool to discuss land use planning, including infrastructure and territorial integrity with government agencies. The map was also printed and distributed in all villages to be used as supporting material for teaching in the schools within the ITs. Nevertheless, 10 years later, the maps in the schools have remained folded. The appropriation of the map by the community as a tool to reflect on territorial issues and orient resource use and management has been 
limited. One of the reasons stated was that the map contained too many layers of information making comprehension difficult by the majority of the people. As already stated, the process of discussing the territory and building the map was carried out by a small number of individuals trained in particular cartographic (IEA) skills that are not shared by many people in the community.

In the broader context indigenous, mapping exercises have been part of the development of Territorial Management Plans of Indigenous Territories (PGTA) in different regions of Brazil as a planning tool that should reflect indigenous aspirations and perspectives regarding their future. Thus they were incorporated as an official management tool in the National Policy for Territorial and Environmental Management of Indigenous Lands in Brazil (PNGATI, Decree 7747 06-05-2012) signed in 2012 (Brasil 2012). The policy aims at promoting the protection, restoration, conservation and sustainable use of the natural resources of ITs, assuring the integrity of the indigenous heritage, the improvement of their quality of life and the conditions of cultural and physical reproduction of their current and future generations, respecting their sociocultural autonomy, and the Brazilian current legislation (Brasil 2012).

\section{A second experience of indigenous participatory mapping as part of the National Policy for Territorial and Environmental Management in Indigenous Lands}

11 In 2011, as part of a pilot project to implement PNGATI, the Indigenous Territories of Oiapoque were selected to receive financial support from the Global Environmental Facility $^{3}$ in support of their ongoing land management initiatives. The Oiapoque Indigenous Peoples had already constructed their PGTA in 2010 (Mazurek 2013) and had started implementing several resource use management actions. At the time they were discussing the revision to update of the first (2001-2003) participatory map with the partner NGO Instituto de Pesquisa e Formação Indígena (Iepét) as part of a new project to be financed by the Brazilian Government. The author of this paper was deeply involved in both processes and spent considerable time in the villages while working for TNC and Iepé from 2010 to 2014. Among the priority actions defined by the Council of the Indigenous Chiefs from Oiapoque (CCPIO) and long time supporters TNC, Iepé and the local office of Brazilian Agency for Indigenous Affairs (FUNAI) was to carry out a second participatory mapping of the territory focusing on land use planning using ethnozoning (Little 2006, Brasil 2012). It was decided to use a different methodology to the previous mapping exercises in order to involve and promote appropriation by more people in the villages to avoid restricting participation to those groups, like the IEAs, that frequently participate in local capacity building initiatives concerning territorial use and management.

\section{Methodology}

The strategy consists of working inside the village, or walking around the village and territory, collectively constructing mental maps at the village scale with community members of different gender, age, personal knowledge and experience. We would meet daily for half a day in the school or community center to talk, understand, register and 
draw on paper territorial cultural use practices and regulations to improve territorial management, i.e. land management for sustainability with the additional challenge of securing the borders of the territory. From the mental maps built collectively we expected to define a local classification of land use, including use intensity as well as identifying local management rules. We would then discuss their effectiveness to provide guidelines to improve territorial and resource use planning in the long term (Mazurek 2014).

For the purposes of this paper, we define ethno-mapping as the geographical distribution of natural and cultural elements as portrayed by the people together with the oral tradition registered during the mapping process, and ethno-zoning as a normative tool that defines specific areas (or zones) for particular uses such as hunting, conservation and expansion of agriculture. These ethno-zoning would then guide specific actions both within the ITs limits and in the surrounding areas to achieve long term sustainability (Little 2006).

\section{Study area}

The Indigenous Territories Uaçá, Galibi and Juminã are located in Eastern Amazonia, in the north of the Amapá state $\left(142,815 \mathrm{~km}^{2}\right)$ on the border with French Guiana (Figure 1). Together these three Indigenous Territories cover a contiguous area of $5,180 \mathrm{~km}^{2}$ comprised of a mosaic of ecosystems including mangroves, savannas and rocky hills and are dominated by lowland tropical forest and seasonally flooded grasslands (Figure 2) (Barros et al. 2013). Large patches of açai berry (Euterpe oleracea) and buriti or moriche ( Mauritia flexuosa) palms are found in the area particularly within the Uaçá Indigenous Territory. Açai berries are appreciated for their high contents in anti-oxidants and large quantities are exported from Brazil as demand from health-conscious citizens from developed nations has increased The fruits of the buriti are very tasteful and rich in oils and have many uses, as uasei berries or açai also have for indigenous and regional people of Amapa (Mazurek et al. 2016). They are also important for many animal species (birds, monkeys, tapirs, peccaries, fish). 
Figure 1 : Map of the Indigenous Territories Uaçá, Juminã and Galibi and the villages where participatory mapping was carried out (white circles)

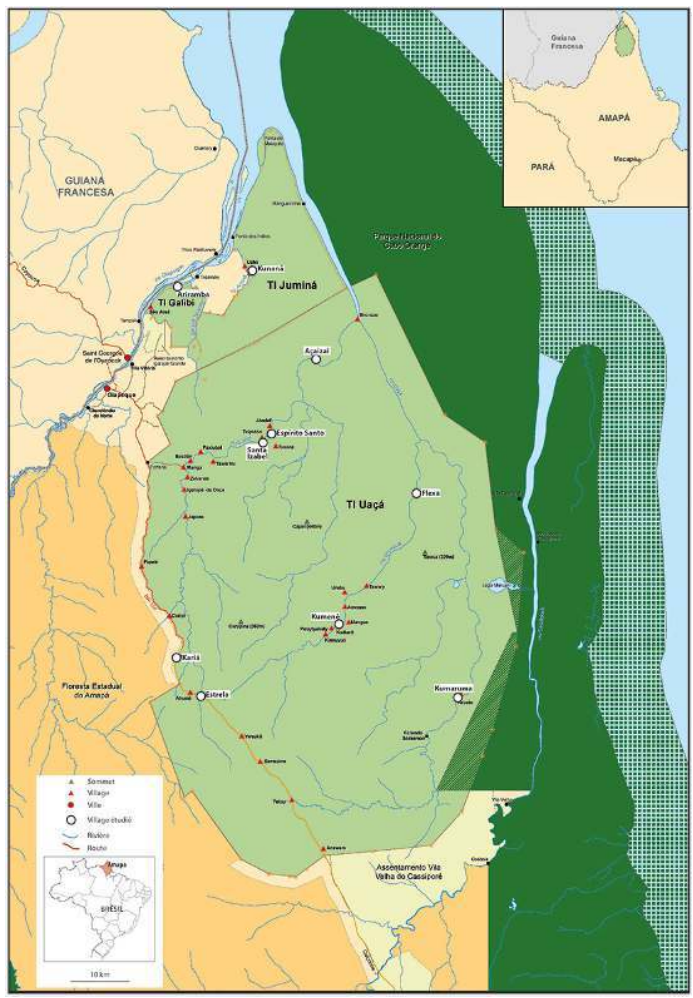

Credits: Instituto lepé

Figure 2 : General landscape of Uaçá Indigenous Territory showing flooded grasslands, islands where villages are located and mountains in the terra firma forest areas

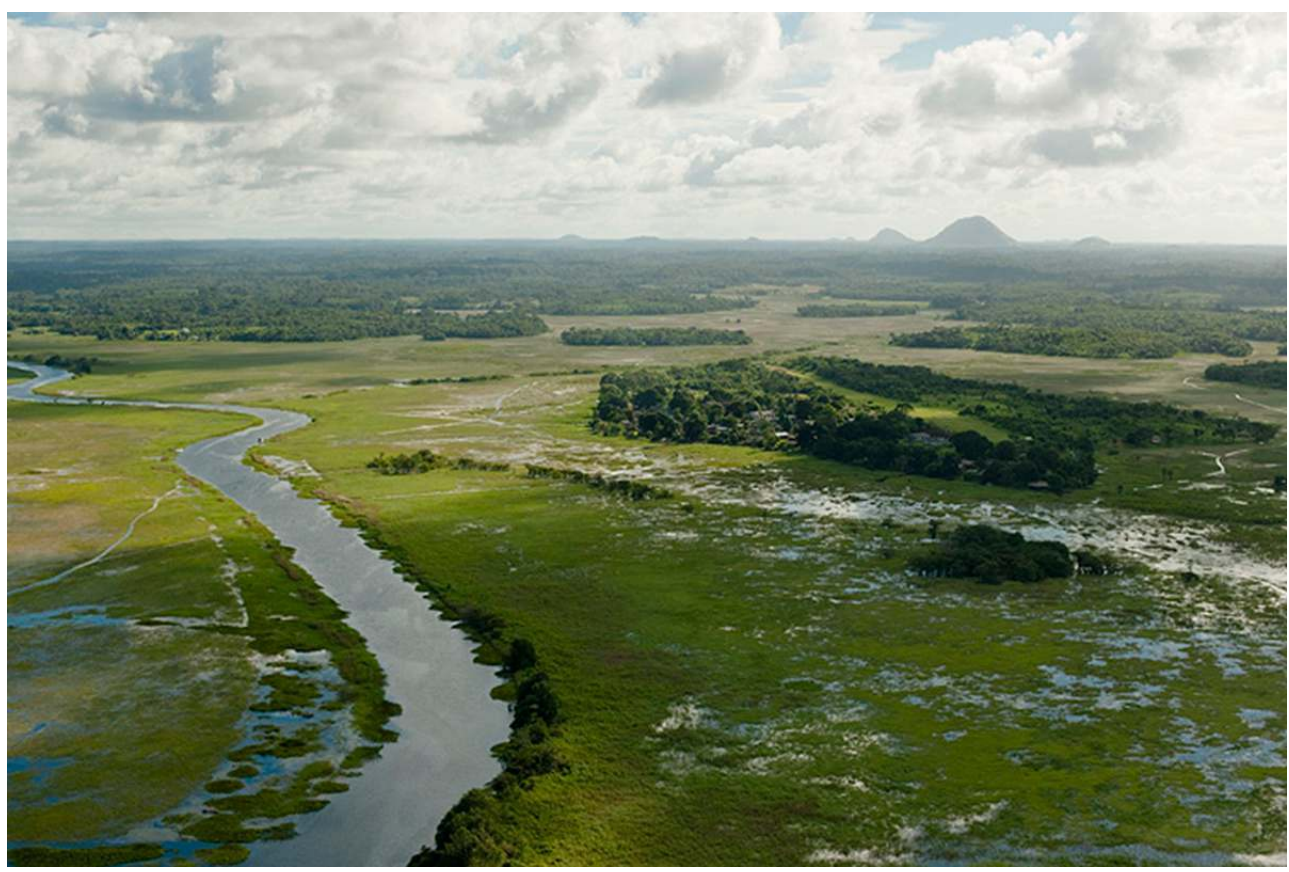

Credit H. Palo Jr. 


\section{The peoples}

15 The Karipuna, Palikur, Galibi Marworno e Galibi Kali'na or « the Indigenous Peoples of the Oiapoque Region » as a collective political identity assumed by them are the result of several migration and ancient and recent ethnic fusions including non-indigenous people (Vidal 2001a et b, Gallois \& Grupioni 2003, Tassinari 2003). They have heterogeneous cultural traditions and distinct histories and trajectories in the contact with the nonindigenous society reflected also in their language and religion. Each ethnic group occupies its own territory located on the banks of the major rivers within the same Indigenous Lands and have detailed knowledge about their environment (Sztutman 2002). They speak aruak (Palikur), carib (Galibi-Kali'na) and patoá (Karipuna and GalibiMarworno). Patoá or French creole is spoken as a common language. The fact that they share the same territory and are under common geopolitical contexts maintains the strong social links and lead them to fight together for their rights and plan the use of the territory collectively. They have important political, social and commercial relations with the city of Oiapoque and with French Guiana where they frequently go to visit their relatives (most of the indigenous people of the region continue to live in both countries as did in the past before geopolitical borders were defined) where they sell their agricultural products and buy manufactured goods that are part of their lives.

The indigenous population size is around 7000 people with each ethnic group having its own territory located on the banks of the Uaçá, Curupi, Urucauá and Oiapoque rivers. The majority of the indigenous population in located in Uaçá IT distributed in 45 Karipuna, Palikur and Galibi Marworno villages ranging from 40 to 2000 people $(470,216.4 \mathrm{ha})$. There are two small villages (one Galibi Kali 'na and one Karipuna) in the Galibi IT (6,690 ha) and 2 Karipuna and Galibi Marworno villages in Juminá IT $(41,601)$. Some villages belonging to several ethnic groups were established along the axis of Highway 156 (connecting Brazil and French Guiana) to ensure territorial protection when, in the 1980s, the road was built by the government against indigenous will. The road is not only a source of local environmental degradation but also of escalating problems as it has made the Indigenous Territories more prone to invasion as it attracts new settlers. Indigenous leaders are currently discussing with government authorities about the mitigation and compensation measures as highway 156 is in the process of being paved. This is expected to bring more negative socio-environmental impacts (Vidal \& Giannini 2006).

\section{Methods}

The study was carried out in 10 villages along Highway 156 in the Indigenous Territories Uaçá, Galibi and Juminã from October 2013 to August 2014 (Figure 1). The villages were selected by the Council of the Chiefs of the Oiapoque Indigenous Peoples (CCPIO) together with TNC, Iepé and Funai to represent all three indigenous lands, the various geographical units and the ecosystems occupied by each ethnic group. The intent was to record and understand the patterns of spatial and resource use among the villages. Each village was visited for 7 to 11 days in different seasons and adapted to people's availability to accompany the participatory mapping process.

The field activities consisted of daily group meetings held in communal houses or places in each village. The discussions were initiated by asking people what they remembered 
from the previous ethno-mapping experience carried out by the IEAs in 2001-2003. As people started talking the subjects naturally expanded towards local perceptions of the surrounding environment; local classifications to represent the natural elements and habitats; biological diversity, temporal and spatial patterns distribution of terrestrial and aquatic flora and fauna and the associations of such species to particular habitat types; hydrology, relief, location of villages; cultural dimensions of the physical geography and of the landscape; toponyms and local classification of habitats; past and current geographical patterns of resource use; lakes, portions of rivers and caves that are the home of spiritual beings; external and internal threats to the territory and the natural resources; possible evidence of scarcity of a particular resource and the necessity of management interventions; cultural practices of resource use rules and regulation.

Once the major local categories of landscape and the distribution of the natural resources into the different habitats and areas have been discussed, the information was then registered in Patoá, Portuguese or Palikur language (depending on the village) on paper and organized by young indigenous people and indigenous teachers to be used during the mapping. The collective discussion then shifted towards mapping, their past and current uses, what they can show and hide, the decisions people can make on the information they want to show when producing a map; examples of how different indigenous people have been using maps for and, above all, discuss how indigenous people could use mapping to value the indigenous knowledge and perceptions about the territory they live in and about the natural environment.

20 We used large pieces of paper to collectively draw the sketch maps based on the information assembled. Once this first part of the map was completed we added an additional layer of information related to local intensity of land and resource use categories as well as its seasonal dynamics and according to cultural regulatory rules.

21 The local categories of land use and intensity, and the geographical distribution of remarkable geographic elements and spiritual sites were displayed on the maps to illustrate existing culturally established "zones» (ethno-zones) under differential exploitation regimes within the indigenous territorial limits. These "zones" were analyzed collectively considering how and what they are used for and how effective they have been in maintain important resources available to the indigenous population in the long term. When the Indigenous People conclude that there have been some negative trends they could then redefine these geographical areas or collectively agree to change the use intensity levels e.g. through regulation of hunting or fishing according to their interest and purposes. It is a delicate and complex negotiation process involving several villages each with their own political interests.

An important part of the methodology was the inclusion of field trips guided by the elders to visit culturally meaningful places that were mentioned during the map construction but were never visited or were unknown by many of the participants, particularly among the younger generation. During the trip, young participants interviewed and recorded (including through photography) myths and histories associated to places or elements told by the elders to promote dialogue and intergenerational learning experiences, thus raising interest among the young to know more about and move within the territory to strengthen cultural identity, promoting social bonds among people and among them and their territory 5 . 


\section{Results and Discussion}

The territories of the 10 villages located on islands in the flooded grasslands and in continuous terra firma forest along the axis of highway 156 were mapped. Rivers and creeks were frequently drawn first on the white paper in the map and served as an important geographical reference to the other elements in the mental landscape. This was particularly evident among the villages living in the flooded grasslands (Figure 3).

Figure 3 : Map making in Açaizal Village in Uaçá Indígenous Territory

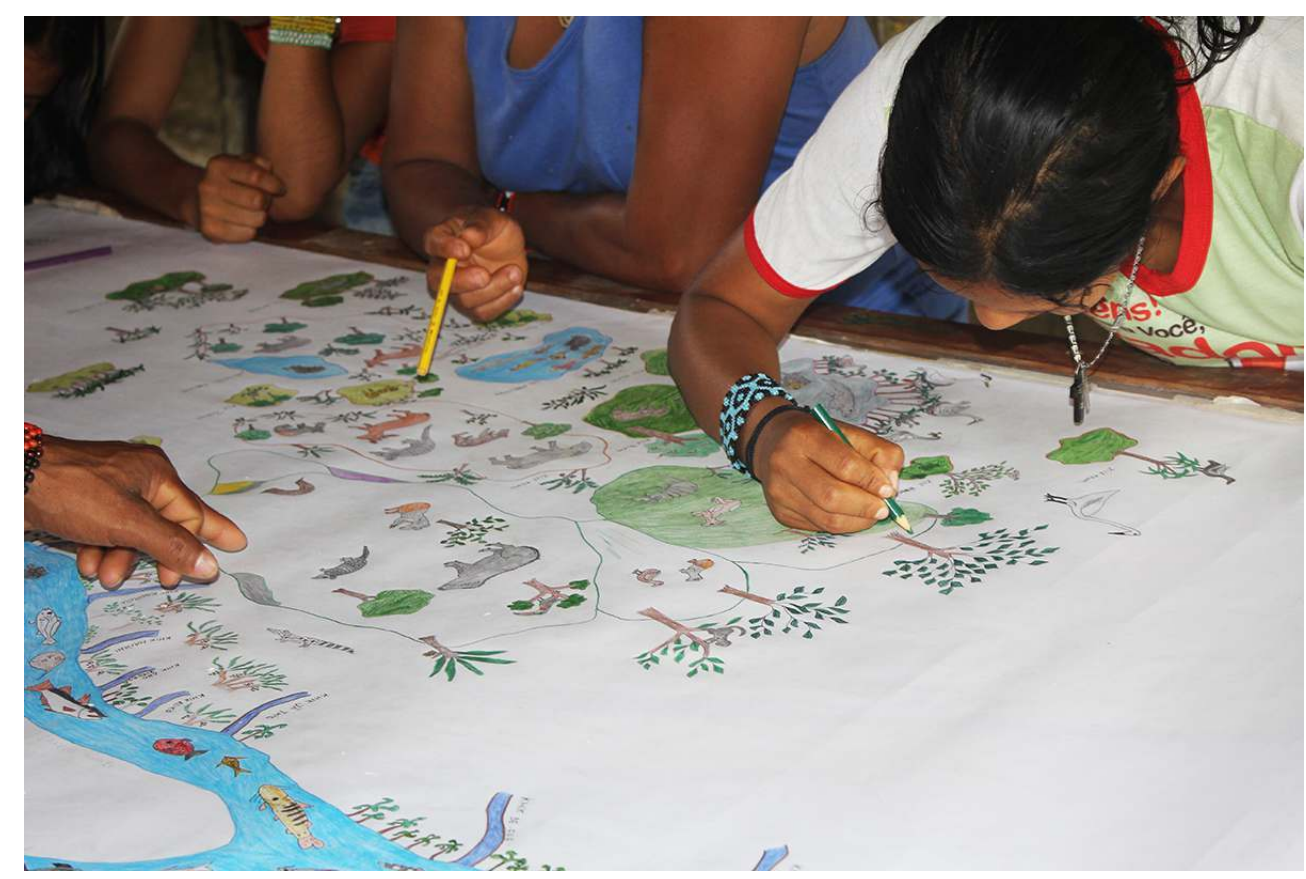

CREDIT : R. REMOR DE SOUZA MAZUREK

The major local environmental categories were then drawn and were based explicitly on the geomorphology: savã (flooded grasslands); ghã te (continuous Terra firma forest); zilê (islands) and lag (lakes) (Figure 4). Finer grain habitat categories included piés buá (gallery forest along major rivers in the flooded grasslands), pinotxe (igapós) or flooded forest on the edge of islands and of continuous terra firma areas; batxi (agricultural grounds or gardens), iamã (abandoned gardens with secondary vegetation), mahikaj (lowland areas near creeks seasonally flooded; it can also refer to areas near the houses where fructiferous species are cultivated). The occurrence of high concentrations of Mauritia flexuosa and Euterpe oleracea palms in the territory are described as piés bax and piés uasei respectively (Figura 5). 
Figure 4 : Detailed view of the map from Açaizal Village from Uaçá Indigenous Territory

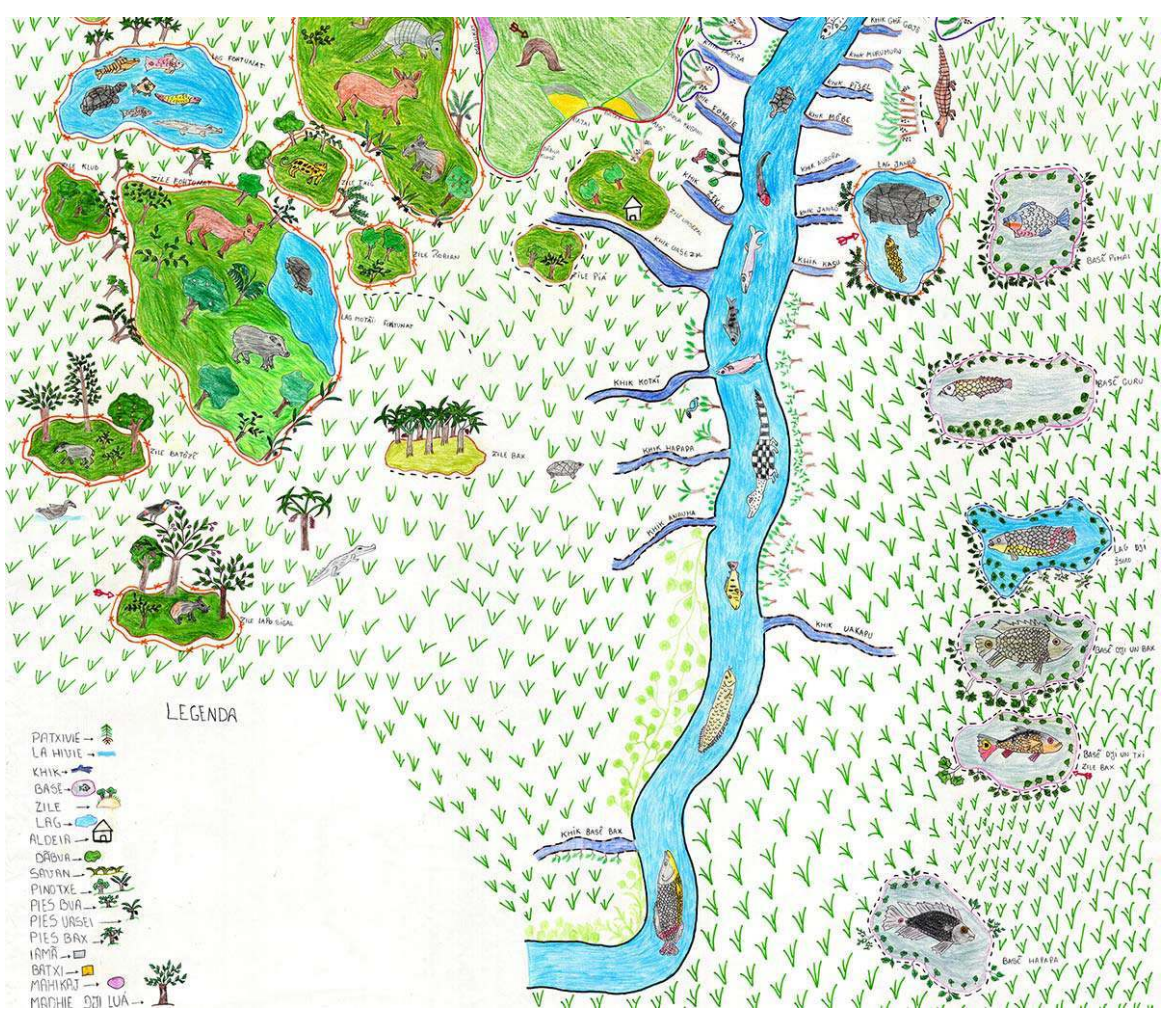

Arrows=places with the presence of " owners »; continuous red line=intensive hunting; dotted lines=low intensive fishing; orange lines=conservation areas

CREDIT: PEOPLE OF THE AÇAIZAL VILLAgE FROM UAÇÁ INDIgENOUS TERRITORY

Figure 5 : Lake with patches of Mauritia flexuosa. Uaçá Indígenous Territory

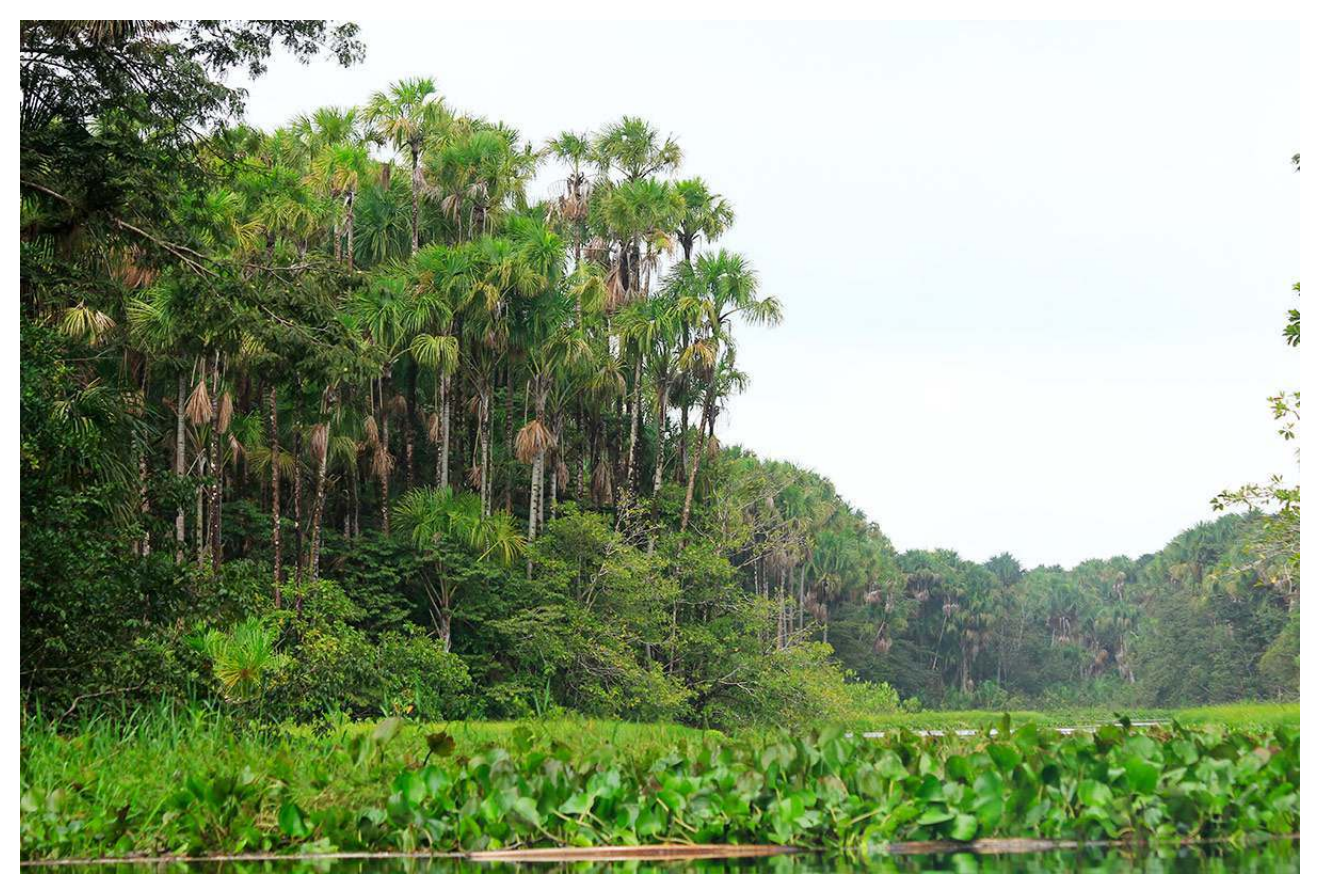

CREDITS: R. REMOR DE SOUZA MAZUREK 
comitantly, the toponyms, spatial and temporal distribution of terrestrial and aquatic species within their natural habitats, the reproductive sites of aquatic bird species and cultural elements associated to specific locations were displayed in detail on the maps.

At least 13 different categories based on the intensity of land use and cultural significance (ethno-zones) were described by the groups in the villages (Table 1) Categories common to all villages were 1,3 4 and 6 . The existing mosaic of different categories of land and resource use reveal a gradient ranging from high to low intensities and is partially associated to proximity to the villages and to seasonal possibilities of access (Muhlen 2005) but also linked to socio-cultural and local management rules. The Cajari Mountain region and the surrounding lakes are used for hunting and fishing rainbow bass (Cichla sp.) to feed participants during religious events (category 5 in table 1) among the Karipuna Villages along the Curipi River.

Table 1 : Categories of areas (or ethno-zones) defined by different types of use and intensity in 10 villages from Uaçá , Galibi e Juminã ITs

\begin{tabular}{|c|c|}
\hline Categories or ethnozones & Description \\
\hline 1. Protection zones or areas rarely used by the Indians & $\begin{array}{l}\text { Areas that people in the village collectively agreed to protect ; in some } \\
\text { cases targets a particular species. Obs. Areas rarely used by the Indians } \\
\text { because are hard to access are included in this category because they } \\
\text { have the same practical function, but are not subject to the same rules }\end{array}$ \\
\hline 2. Zones of use that include the protection of a particular species & $\begin{array}{l}\text { Areas where some activities are allowed and others are restricted. In general } \\
\text { the restrictions focused on the protection of Arapaima gigas and the } \\
\text { freshwater turtle Podocnemis unifilis }\end{array}$ \\
\hline 3. Zones used only in winter (rainy season) for hunting and fishing & $\begin{array}{l}\text { Areas where resources are subject to pressure by local use during only } \\
\text { part of the year }\end{array}$ \\
\hline 4. Zones used only in summer season (dry season - June to November) & $\begin{array}{l}\text { Areas used only during the dry season due to the difficult acess; resources } \\
\text { are subject to pressure only part of the year }\end{array}$ \\
\hline 5. Zones for Ritual Hunting & Areas only used for hunting in religious events \\
\hline 6. Zones of permament use (intense) & Areas used intensively all year around \\
\hline 7. Zone of spiritual beings & Areas associated to the presence of spiritual beings or "owners» of the place \\
\hline 8. Zones of Non-Timber Forest Product (NTFP) extraction & Areas of local abundance and extraction of NTFP of local interest \\
\hline 9. Zones of timber extraction & Areas of local abundance of timber and timber extraction \\
\hline 10. Zones Non-Timber Forest Product (NTFP) management & Areas chosen to manage and particular species of local interest (ex: açai berry) \\
\hline 11. Zones for current and future agriculture & Areas currently used for agriculture and future agricultural expansion areas \\
\hline 12. Zones vulnerables and subjects to invasion & Areas with higher probabilities for invasion by external agents \\
\hline 13. Zones where indigenous lands overlaps with Conservation Unit & $\begin{array}{l}\text { Overlapping areas between Indigenous Lands and Cabo Orange National } \\
\text { Park, in Uaçá }\end{array}$ \\
\hline
\end{tabular}

27 Areas categorized as vulnerable and subject to invasion by outsiders (12) were more frequent in the villages of Juminã and Galibi IT located on the margins and near the delta of the Oiapoque River. The river is one of the limits of both ITs and presents intense fluvial traffic going up and down river on the border of Brazil with French Guiana. There is considerable illegal gold mining activity particularly in French Guiana and it attracts many people to the region. Indigenous People from Juminã and Galibi IT had their boats robbed several times and they often find vestiges of invaders within their territories. Protection categories (1) were present in the villages Flexa (Uaça IT, Urucauá River), Açaizal (Uaça IT, Curipi River) e Kunanã (Juminã IT, Oiapoque River). The Flexa and Açaizal villages have defined zones to protect specific aquatic resources like Pirarucu ( Arapaima gigas) and the river turtle (Podocnemis unifilis). Areas locally categorized for timber extraction and timber protection were found in the villages of Kumarumã and Açaizal. The Gabili Marworno from the Kumarumã Village (2,000 people) are well known for constructing high quality canoes of different sizes and styles which are sold to people in the region including in French Guiana. Currently, good quality wood is getting scarce within the IT also due to intense use for housing construction. Villagers particularly 
mentioned the decline of several species from Lauraceae family and Black manwood ( Minquartia guianensis).

\section{Mapping to register and think together?}

The current methodology allowed people of different ages and experiences to share knowledge on the spatial and temporal distribution and abundance of particular natural resources and evaluate changes over time and reflect upon the reasons why. This reflection often extrapolated the spatial scale of the village into changes in land use and transformations of the landscape in the regional context in which the indigenous lands are found. The presence of highway 156 crossing Uaçá IT for $44 \mathrm{~km}$ from south to north is frequently associated to negative impacts such as working as a physical barrier to the movement of important faunal species to the Indigenous Peoples such as the Whitelipped Peccary (Tayassu pecari). Two comments highlight the local perception of the importance of having large tracts of continuous forests that allow game to move between areas of different game use intensities:

In the past there were a lot of white lipped peccaries here. Now they are gone. I think this road (highway 156) scared them away. They use to come from the Tumucumaque (area located west of Uaçá Indigenous Territory where is currently Tumucumaque National Park (L.F., Ariramba Village)

Here, on this part the land is all in one big piece. It is all lowland rainforest. Game species all come from there (M.T.A., Manga Village).

The logic of connectivity expressed in these words is similar to the ecological corridors used as a conservation strategy to reduce the impacts of habitat fragmentation on fauna species by allowing the flux of animals and genes between habitat patches.

The distribution of historically meaningful places and the toponyms of the elements portrayed on the maps by the Indigenous Peoples promoted curiosity and reflections about their meanings. It also revealed gaps but also possibilities of learning exchange between elders and the young using cartography as a tool:

I did not even know that the elders use to move over this huge area within our territory in the past! Nowadays we go fishing in the nearby lakes and rivers and we never think about the meaning of the name of the lake or what has happened there in other times. I don't even know why the Araramã Lake is called that way. Now here, talking to Mr Emiliano Iapaha (Palikur) I learned that Aramamã, is the name of a mythical snake, that takes care of the lake, that also has a different name in Palikur. (C.S.M. $7^{\text {th }}$ grader Santa Izabel Village).

\section{Ethno-mapping and environment conservation?}

Cultural knowledge and beliefs potentially play a role in resource use and management (Ross 1978, Colding \& Folke 2001, Barre et al. 2009, Maffi \& Woodley 2012). Several particular places, frequently related to lakes and mountains, were signaled in the maps as the home of beings from the spiritual world called «donos", which means owners in portuguese. The Indigenous Peoples of Oiapoque say that the owners protect particular places and observe and react if the people are not using the resources according to rules culturally established. Several narratives or myths associated with natural resource abundance and rules of use were registered by the young through interviews with the elders during the ethno-mapping process. Two narratives collected follow mostly similar 
threads in which "owners » reveal secrets through dreams or spiritual communication with the Pajés (shaman) about specific places of great resource abundance for the Indigenous Peoples to use. Nevertheless, the owners also warn them about the problems of overusing, about the rules and the risks in case of disobedience. For example, in two narratives the people did not respect the owners' rules by going too often and collecting excessive amounts of fish and turtles. The disrespectful attitude infuriated the owner who turned the lakes permanently invisible and inaccessible to people as punishment. According to participant's testimonies the places that have owners are treated with respect and are often even feared by the local people who avoid going there. One consequence for the territorial use planning is that these areas, spread over several parts of the landscape, represent zones of low use intensity where the abundance of aquatic and terrestrial faunal species are likely be higher. Depending on the connectivity among them, areas of low use intensity use can potentially work as " source areas » supplying faunal species to the areas where they are heavily extracted by the Indians (« sink areas » ). Areas under low hunting pressure have higher densities of game species when compared to areas heavily hunted in Amazonia (Peres \& Dolman 2000, Rosin \& Swamy 2013). Such source and sink models have been applied in conservation to analyze the longterm sustainability of hunting practices by native communities elsewhere (Novaro et al. 2000).

32 Talking about the myths and cultural rules established collectively and their effect on regulating resources would inevitably lead the group to reflect about to what extent people respect and comply with rules and the consequences this may have for social cohesion and territorial use planning within the Indigenous Territories in the long term.

One additional aspect that is important to be considered is that, mapping the distribution of resources and the patterns of movement of people for subsistence over the territory can raise suspicions and people if the reasons for doing so are not clearly stated and agreed upon by the group and people conducting the process. By materializing areas of use by specific villages on the map may also expose otherwise subliminal existing internal political divergences or disputes over areas of high abundance of a particular important resource such as Açai berry. One phrase an influent leader of the Galibi Marworno ethnic group about the process of discussing the land use categories within Oiapoque IT illustrates this concern:

The limits of our territories were established by our history and it is clear inside our heads. The act of placing them over a map is not to divide ourselves but to help us to plan better the use of the territory and its resources in the long term (...) (D.S.R)

The opportunity rose by the process of assembling together and talking, when people do not normally take the time to do it, is multifold. To take the time to visit places, draw landscape features, remember events and histories, write and correct toponyms and geographical locations based on experience and cultural perspective and the information that appears naturally during these moments reaches far beyond the issues that started the dialogue (Figure 6). This is a fundamental point because it promotes an opportunity for local protagonism, more freedom to discuss different aspects of the territory and a greater appropriation of an " exogenous » tool of an abstract graphic representation of something that is an intrinsic part of their lives. It also highlights the importance of one aspect of the methodology that was to spend more time in the village during the mapping activities to include visits to important (but not only) locations that were present in the 
maps built (Figure 7). Not everyone knows or takes the time to go to visit or to explore the more distant areas within the territory. People's circulation over the territory seems to have greatly decreased in three generations according to reports of people from the villages (Mazurek 2015). This is probably associated to socioeconomic changes including the presence of schools in the villages, access to paid jobs and access to government social benefits. This trend is even more obvious among the young people of the new generations even for places relatively close to the villages where they live. During the mapping process the increasing interest of the young people to consult and ask the elders was noticeable but it also incited a reciprocal desire of the elders to remember and transmit the knowledge they acquired both by experience and by transmission from their parents and grandparents.

Figure 6 : Mapping workshop and video recording by indigenous teachers at Espirito Santo Village in Uaçá Indígenous Land

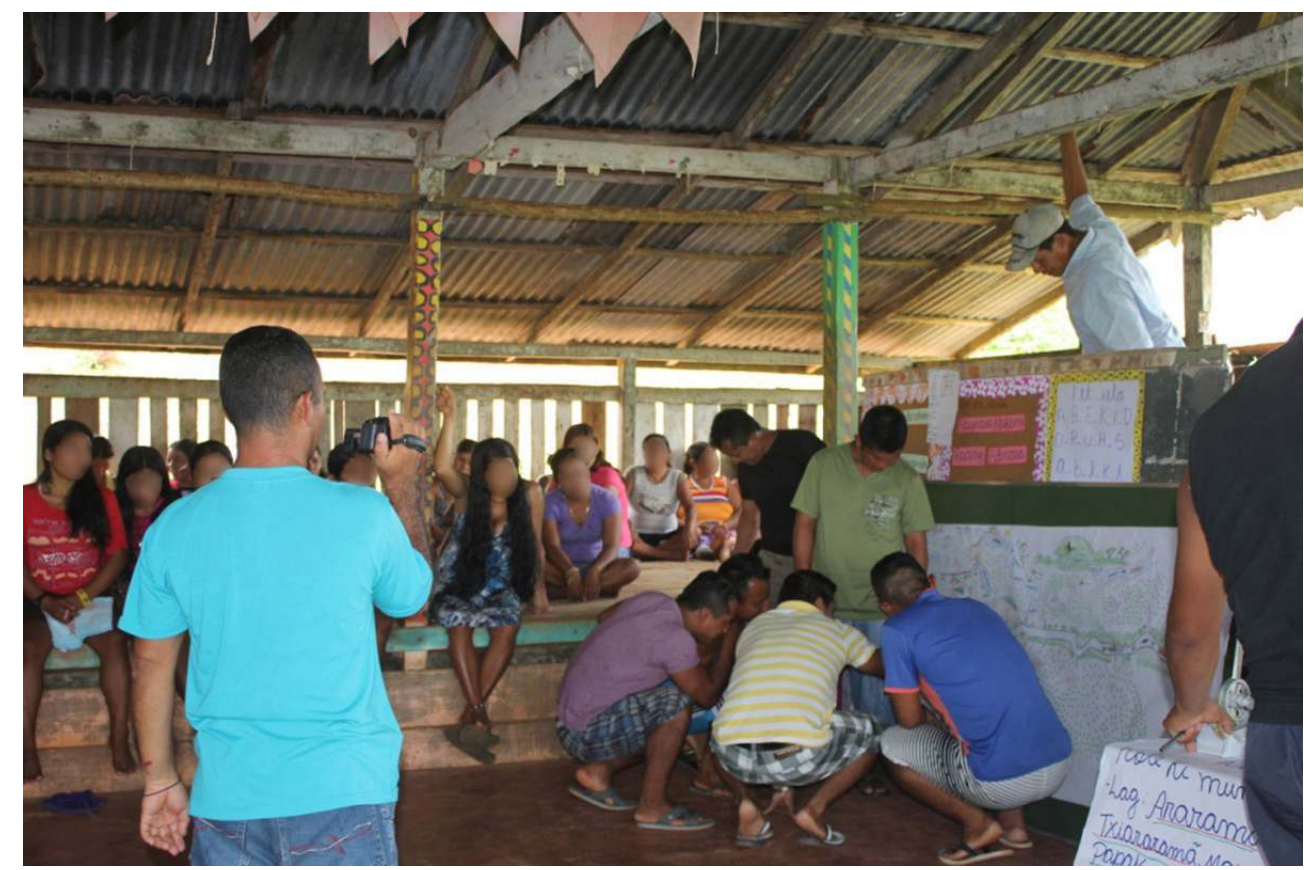

CREDITS: R. REMOR DE SOUZA MAZUREK

The trips of young people to visit unknown sites within the territories accompanied by elders promotes interest and motivation in knowing their territory better, find out about their history in an adventurous way what is attractive to young people (Figure 7). This type of practice can contribute to strength their cultural identity and social bonds among people and between them and their territory. This is important in a social context when an increasing number of young Indians leave the IT to live in Oiapoque to study or look for work. The trips carried out during the mapping influenced two indigenous institutions to organize two visits guided by the elders to important lakes located in areas in the limits of the indigenous territory. The lakes are subject to heavy illegal fishing from outsiders of partial the limits of the territories and were also depicted in the mapping. The visits to strategic places vulnerable to invasions also make indigenous people more aware of territorial issues within broader regional contexts in which the IT are inserted and potential new territorial threats posed by the paving of highway 156 as 
well as population increase along the road axis and its neighboring areas and the city of Oiapoque urban expansion.

Figure 7 : Young indigenous people during field trip to Araramã Lake Uaçá Indigenous Territory

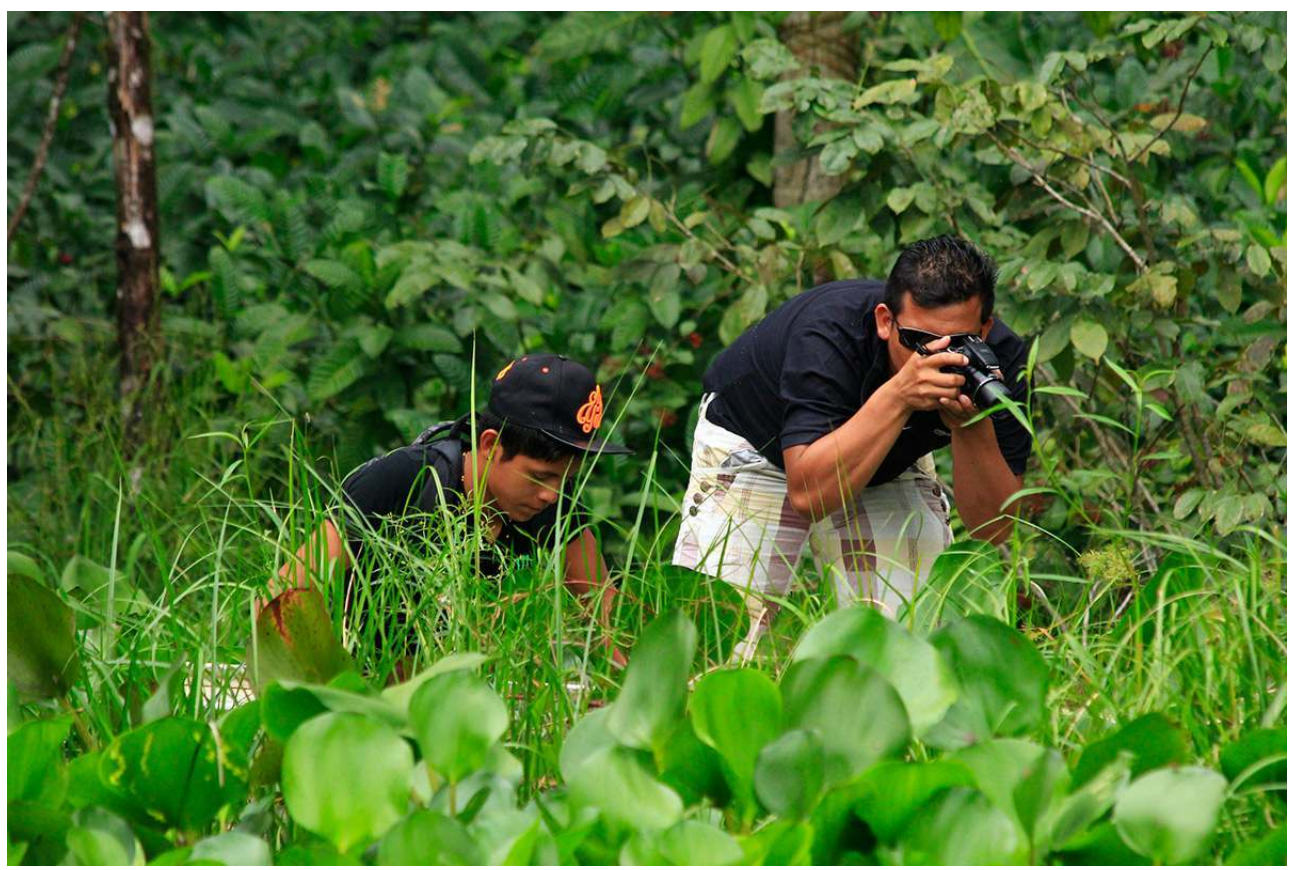

CREDITS: R. REMOR DE SOUZA MAZUREK

\section{Conclusion}

The initial idea of this second collective mapping exercise was not only to map the distribution of the different land uses and intensities in each village but also to favour local appropriation of the process and establish a base for local territorial planning. In addition the exercise revealed itself as an important opportunity for people to reflect on the cultural dimensions associated with the surrounding landscape. One of the outcomes of the mapping exercise is that it created a time to reflect on the present and the future in an institutionalized and collective way. Discuss territorial management and land and resource use are part of complex social and dynamic process that are probably more urgent for indigenous people today than where in the past. The appropriation of the discussion on this matter by the people collectively is a continuous process in which the strategies used need to be constantly evaluated. Participatory mapping had been initiated 10 years earlier for the "the Plano de Vida " but at another scale, with a different methodology and finality. This study suggests that the way the mapping methodology was approached to discuss land management may be more meaningful to more people living in the villages. It would be insightful to learn about what remained in the communities the next ten years...

\section{Acknowledgements}

I thank to the indigenous people of Oiapoque, particularly in the villages Kumarumã, Açaizal, Kunanã,Flexa, Santa Izabel,Ariramba, Cariá, Kumenê, Espirito Santo and Estrela for all the moments confidence, kindness and knowledge shared during and beyond the participatory 
mapping. This study was financed as part of the institutional agreement among The Nature Conservancy, Instituto de Pesquisa e Formação Indígena-Iepé, FUNAI - GATI Project for the territorial management planning of the Indigenous Territories (Terras Indígenas) of Oiapoque (Brasil). I thank to the CCPIO and the caciques of the participant villages and FUNAI Oiapoque Office for helping to organize the activities in the villages. I am particularly indebted to Ana Paula Nóbrega da Fonte and Gina Marcela Feitosa da Silva of the Oiapoque Program-Iepé for the support throughout the participatory mapping process. Work package "participatory methodology " were part of the DIPOLOPP Project in Guyamazon-IRD Program research (France/Brasil) P. de Robert, S. Duvail and 0 . Hamerlynck made important contributions to the manuscript during the writing process.

\section{BIBLIOGRAPHY}

Akarib 2007 - Plano de gestão territorial e ambiental da terra indígena Kaxinawá e Ashaninka do Rio Breu . Edição e organização Renato Antônio Gavazzi. Rio Branco, Comissão Pró-Índio do Acre, 69 p.

Allegretti M. 1994 - Reservas extrativistas: parâmetros para uma política de desenvolvimento sustentável na Amazônia. In Anderson A. et al. o Destino da Floresta reservas extrativistas e desenvolvimento sustentável na Amazônia. Rio de Janeiro, Relume Dumará : 17-67.

APIO 2009 - Plano de vida dos índios e organizações indígenas do Oiapoque. Oiapoque, 45 p.

Apiwtxa 2007 - Plano de gestão territorial e ambiental da terra indígena Kampa do Rio Amônia. Rio Branco, Comissão Pró-Índio do Acre, 83 p.

Apolinário J. 2012 - Etnomapeamento das Terras Indígenas Timbira/Plano de Gestão Territorial e Ambiental das Terras Indígenas Timbira. Maranhão, Brasil, Associação Wyty-Catë das Comunidades Timbira do MA.

Arias P.D. 2003 - Nosotros vamos a dibujar nuestro propio espacio territorial. Reapropiación del territorio y apropiación de la Cartografía en la Zonal Pewence. Undergraduate thesis. Corpus. Archivos virtuales de la alteridad americana 2 (1) : 1-79.

Albert B., Robert P. de, Laques A.E \& Le Tourneau F.M. 2011 - From amerindian territorialities to « indigenous lands » in the Brazilian Amazon: the Yanomami and Kayapo cases. In Aubertin C. \& Rodary E. (Ed.) Protected areas, sustainable land? Farnham (GBR), Ashgate ; Marseille, IRD : 123-141. Barre R.Y., Grant M. \& Draper D. 2009 - The role of taboos in conservation of sacred groves in Ghana's Tallensi-Nabdam district. Social \& cultural Geography 10 (1) : 25-39.

Barros L.P, Mazurek R.R.S, Balieiro C.P.P, Amora P.B. \& Sztutman M. 2013 - Etnomapeamento como instrumento de apoio à classificação da tipologia florestal nas terras indígenas Uaçá, Galibi e Juminã, no estado do Amapá. XVI Simpósio Brasileiro de Sensoriamento remoto. Foz do Iguaçu. 13-18 de Abril : 3191-3198.

Brasil 1988 - Constituição da República Federativa do Brasil. URL: http://www.planalto.gov.br/ ccivil_03/constituicao/constituicaocompilado. 
Brasil 2012 - Decreto n. 7.747, de 5 de junho. Institui a Política Nacional de Gestão Territorial e Ambiental de Terras Indígenas - PNGATI, e dá outras providências. Casa Civil. Accessed in 10 June 2012. Available online: URL: http://www.planalto.gov.br/ccivil_03/_ato2011-2014/2012/ decreto/d7747.htm

Carneiro Filho A. 2009 - Atlas de pressões e ameaças às terras indígenas na Amazônia brasileira. São Paulo, Instituto Socioambiental.

Chambers R. 2006 - Participatory mapping and geographic information systems: whose map? Who is empowered and who disempowered? Who gains and who loses? The Electronic Journal of Information Systems in Developing Countries 25 (2).

Chapin M., Lamb Z. \& Threlkeld B. 2005 - Mapping Indigenous Lands. Annual Review of Anthropology $34: 619-639$.

Colding J. \& Folke C. 2001 - Social Taboos: invisible systems of local resource management and biological conservation. Ecological Applications 11 (2) : 584-600.

Corbett J., Rambaldi G., Kyem P., Weiner D., Olson R., Muchemi J. \& Chambers R. 2006 - Overview: mapping for change-the emergence of a new practice. Participatory learning and action 54 (1) : 13-19.

Cronketon P.M.A., Albornoz G., Barnes K.E. \& W. de Jong 2010 - Social Geomatics: Participatory Forest Mapping to Mediate Resource Conflict in the Bolivian Amazon. Human Ecollogy 38 : 65-76.

Do Vale S., Souza M. De \& Souza. E. B. 2012 - Etnomapeamento e Plano de Gestão Territorial e Ambiental das Terras Indígenas de Roraima (Conselho Indígena de Roraima - CIR): In Goulart A. \& Barreto Filho H.T. (Org.), Seminário Internacional de Mapeamentos Participativos de territórios indígenas na Amazonia. Rio Branco, Acre.

Eliana L.S, K. Sherrod, \& Langdon S. J. 1985 - Subsistence Mapping: an evaluation and Methodological guidelines. Technical Paper. Alaska Department of fish and Game.

Fleury M., Alupki T., Opoya A. \& Aloïké W. 2016 - Les Wayana de Guyane française sur les traces de leur histoire. Cartographie participative sur le Litani (Aletani) et mémoire orale. Ethnoécologie

FUNAI (Fundação Nacional do Índio) 2002 - Manual do Ambientalista. Programa Piloto para a Proteção das Florestas Tropicais do Brasil - PPG7. Programa Integrado de Proteção às Terras e Populações Indígenas da Amazônia Legal - PPTAL. Brasília, FUNAI, 39 p.

Herlihy P.H. \& Knapp G. 2003 - Maps of, by, and for the Peoples of Latin America. Human Organization.62 : 303-314.

Gallois D.T. \& Grupioni D.F. 2003 - Povos indígenas no Amapá e Norte do Pará. Quem são, onde estão, quantos são, como vivem e o que pensam? São Paulo, Iepé.

Gavazzi R. 2012 - Agrofloresta e cartografia indígena: agestão territorial nas mãos dos agentes agrorestais indígenas do Acre. Master Thesis.Universidade de São Paulo -USP. 297 p.

Goulart A. \& Barreto Filho H. (Ed.) 2011 - Mapeamento participativo e gestão de territorios indigenas na Amazônia. Brasilia, Instituto Internacional de Educação do Brasil IEB.

Instituto Socioambiental 2016 - https://pib.socioambiental.org/pt/c/0/1/2/populacao-indigenano-brasil

Kahwage C.M.C. \& Marinho H.M. (Ed.) 2011 - Situação socioambiental das Terras Indigenas do Para. Desafios para a elaboraçao de politicas de gestao territorial e ambiental. Belem, SEMA.

Koch-Grünberg T. 1982. [1924] - Del Roraima al Orinoco. Vol. III. Caracas, Ed. Banco Central de Venezuela. 
Little P. 2006 - Gestão territorial em terras indígenas: definição de conceitos e proposta de diretrizes. Technical Report. Secretaria de Estado de Meio Ambiente e Recursos Naturais - SEMAAC. Secretaria Extraordinária dos Povos Indígenas -SEPI - AC and GTZ.

Maffi L. \& Woodley E. 2012 - Biocultural diversity conservation: a global sourcebook. Routledge.

Mazurek R.R.S.2013 - Programa de Gestão Territorial e Ambiental das Terras Indígenas do Oiapoque (Org.) Belém, The Nature Conservancy, 24.

Mazurek R.R. S. 2014 - Coming back on a participatory mapping experience with a new methodological focus in indigenous territories of Amapa (Brazil). 14 ISE, symposium Participatory Methods, Bumthang, Bhutan, june 2014.

Mazurek R.R.S. 2015 - Andar no Território: intercâmbios locais para conhecer, valorizar e proteger o seu lugar. Technical Report Instituto de Pesquisa e Formação Indígena-Iepé.

Mazurek R.R.S., da Fonte P. \& Robert P. de 2016 - Uasei berry (Euterpe oleracea Mart.) in the gourd of the indigenous people of Oiapoque. International Conference on Food Heritage \& Culinary Practices Université Pierre et Marie Curie. October 14-16th 2015. Paris.

Molo A.J. \& E.L. Zent 2012 - Autodemarcacion de los Territorios Indígenas Jodï y Eñepa, estados Amazonas y Bolívar, Venezuela. In Goulart A. \& Barreto Filho H.T. (Org.) Seminário Internacional de Mapeamentos Participativos de territórios indígenas na Amazônia. Rio Branco, Acre.

Mühlen E.M. von 2005 - Consumo de proteína animal em aldeias de terra firme e de várzea da Terra Indígena Uaçá, Amapá, Brasil. Belém, Museu Paraense Emílio Goeldi.

Neff G.K.R \& Ortiz N. 2012 - Cartografía Cultural en el Territorio de los Jaguares de Yuruparí con la organización indígena ACAIPI (Asociación de Capitanes y Autoridades Tradicionales Indígenas del río Pira Paraná) In Goulart A. \& Barreto Filho H.T. (Org.) Seminário Internacional de Mapeamentos Participativos de territórios indígenas na Amazônia. Rio Branco, Acre.

Novaro A.J., Redford K.H., \& Bodmer R.E. 2000 - Effect of hunting in source-sink systems in the Neotropics. Conservation Biology 14 (3) : 713-721.

Peres C.A. \& Dolman P.M. 2000 - Density compensation in Neotropical primate communities: evidence from 56 hunted and nonhunted Amazonian forests of varying productivity. Oecologia $122: 175-189$.

PPTAL 2004 - Levantamentos etnoecológicos em terras indígenas na Amazonia brasileira: uma metodologia. http://www.mma.gov.br/estruturas /168/_arquivos/168_02122008054922.pdf

Rosin C. \& Swamy V. 2013 - Variable Density Responses of Primate Communities to Hunting Pressure in a Western Amazonian River Basin. Neotropical Primates 20 (1) : 25-31.

Roldán Ortega R. 2004 - Models for recognizing indigenous land rights in Latin America. World Bank Biodiversity Series 99, 33 p.

Povo Manoki 2012 - Plano de Gestão Territorial Manoki. Operação Amazonia Nativa. OPAN, 70 p.

Robert P. de, Faure J.F., Laques A.E. \& the people of Moikarakô 2006 - Cartography with an Indigenous People in the Brazilian Amazon: the power of maps in the Kayapo's experience. In Corbett J. et al. (Org.) Mapping for change: practice, technologies and communication. London, International Institute for Environment and Development (IIED), Technical Centre for Agricultural and Rural Development (CTA) : 74-78 (Participatory Learning and Action ; 54).

Ross E. 1978 - Food Taboos, Diet and hunting strategies: the adaptation to animals in Amazon Cultural ecology. Current Anthropology 19 (1) : 1-30. 
Sztutman M. 2002 - Levantamento Sócio Ambiental dos Povos Indígenas de Oiapoque.Technical Report. Macapá, Governo do Estado do Amapá, Secretaria de Estado da Indústria, Comércio e Mineração, Gabinete da Secretaria.

Tassinari A.M.I. 2003 - No Bom da Festa. O Processo de Construção Cultural das Famílias Karipuna do Amapá. São Paulo, Editora da USP, 413 p.

TNC Amazônia 2006 - Etnomapeamento nas Comunidades Indígenas da Amazônia. http:// www.nature.org/wherewework/southamerica/brasil/work/art16607.html.

Trancoso R., Miller R.P., Goulart A., Trindade H. \& Correia C.S. 2012 - EtnoSIGs: Ferramentas para a gestão territorial e ambiental de terras indígenas. In Paese A., Uezu A., Lorini M.L. \& Cunha A. (Ed.) Conservação da biodiversidade com SIG. São Paulo, Oficina de Textos cap.7 : 107-124.

Vidal L. 2000a - Galibi-Marworno. In Povos indígenas no Brasil. Instituto Socioambiental. [en ligne : https://pib.socioambiental.org/pt/povo/galibi-marworno].

Vidal L. 2000b - Galibi do Oiapoque. In Povos indígenas no Brasil. Instituto Socioambiental. [en ligne : https://pib.socioambiental.org/pt/povo/galibi-do-oiapoque].

Vidal L.B. \& Giannini I. 2006 - Estudo Etnoecológico nas Terras Indígenas Uaçá, Galibi e Juminã. Realizado no âmbito do processo de elaboração dos Estudos de Avaliação de Impacto Ambiental. EIA-RIMA da Linha de Transmissão Calçoene/Oiapoque - Eletronorte. Brasília, Eletronorte.

\section{NOTES}

1. It should be noted that the officially recognised Indigenous Territories do not necessarily correspond to what is perceived by the Indigenous Peoples as their land, i.e. what they use and have used in the past. In the text, I make a distinction between "Indigenous Territories » as the official category and the « indigenous land» as a larger area.

2. The final map can be consulted in the Territorial and Environmental Management Plan of the Indigenous Lands of Oiapoque. http://www.tnc.org.br/cs/groups /webcontent/@web/ @brasil/ documents/document/prd_130804.pdf

3. Global Environmental Facility (GEF). http://www.funai.gov.br/index.php/projeto-gati

4. http://www.institutoiepe.org.br/iepe-in-english/

5. Later, to respond to the local demand with the support of the DIPOLOPP Project, I organize a photographic workshop with renowned wildlife photographer Haroldo Palo Junior for young people to acquire autonomy (and machine) to take picture during this trip, and at any moment they wanted.

\section{ABSTRACTS}

Participatory mapping for land use planning in the Indigenous Territories (Terras Indígenas) of Oiapoque, in northeastern Amazonia has been carried out by governmental and nongovernmental organizations in partnership with indigenous institutions. The first mapping exercise was carried out through regional workshops with a selected group of indigenous (Indigenous Environmental Agents) using a georeferenced Landsat satellite image and drawing 
physical and cultural aspects of the territory over the images on paper. In this study, we document an alternative approach started at the village level, included more time consulting with diverse members from the community and collective field visits to sites within the indigenous land. This experience was carried out in ten villages in the Uaçá, Juminã, and Galibi Indigenous Territories (Amapá, Brazil) from October 2013 to August 2014. Results showed detailed classification of the landscape into 13 different local categories of land use and management. The collective mapping process allowed people to reflect and analyze together their current land use and existing management practices. Fields visits were an important aspect of the methodology as for promoting intergenerational exchange of traditional knowledge. The comparison of the two mapping exercises suggests that focus on particular segments of society might achieve limited success if not associated with other strategies to strengthen their interaction with the villages in the long term. Finally, the study questions current practices: what remains of mapping exercises in the community? Do they lead to a better political organization and/or environmental consciousness? Mapping for Territorial Management as conducted here seems to offer the additional and important opportunity to retrieve, remember, discuss and register the history of the community.

Au Brésil, la cartographie participative pour la gestion territoriale des Terres Indigènes (TI) du Oiapoque dans le nord est de l'Amazonie est utilisée par les organisations gouvernementales et non-gouvernementales en collaboration avec les associations amérindiennes depuis plus de dix ans. Le premier exercice de cartographie s'est fait au sein d'ateliers réunissant des Amérindiens sélectionnés pour leur formation (AAI: Agents Indigènes de l'Environnement) qui ont représenté, sur la base d'une image satellitaire LANDSAT géoréférencée, les principaux aspects physiques et culturels de leurs territoires à l'échelle de la région. Dans cette étude, nous documentons une approche alternative commencée à l'échelle villageoise, menée sur un temps plus long, incluant différents membres des communautés et complétée par des visites de sites à l'intérieur du territoire amérindien. Cette expérience a été menée dans dix villages des TI Uaçá, Juminã, et Galibi Indigenous (État de Amapá) entre octobre 2013 et août 2014.

Les résultats donnent une classification détaillée de 13 catégories locales d'utilisation et de gestion territoriales. Le processus de cartographie participative favorise une réflexion et une analyse collectives sur l'usage des terres et les pratiques actuelles de gestion. Les visites de terrain sur les sites choisis stimulent les échanges intergénérationnels autour des savoirs traditionnels. La comparaison des deux exercices de cartographie suggère que l'appropriation de l'outil carte reste limitée si seul un segment particulier de la société est concerné par son élaboration, il est important de travailler aussi les stratégies qui favorisent les interactions entre villages sur le long terme. Finalement l'article questionne nos pratiques communes: que reste-t-il de ces exercices de cartographie participative dans les communautés? Peuvent-ils aider à renforcer l'organisation politique ou/et la conscience environnementale ? La cartographie pour la gestion territoriale telle qu'elle a été menée ici offre une opportunité supplémentaire pour se souvenir, discuter et enregistrer ensemble la mémoire historique inscrite dans les territoires.

\section{INDEX}

Geographical index: Amazonie(nord-est), Brésil, Guyane française

Keywords: Participatory mapping, indigenous people of Oiapoque, public policies, eastern Amazon, border of Brazil and French Guiana

Mots-clés: cartographie participative, peuples amérindiens du Oiapoque, politiques publiques 


\section{AUTHOR}

\section{ROSÉLIS REMOR DE SOUZA MAZUREK}

Instituto de Pesquisa e Formação Indígena-Iepé

Rua Lélio Silva 91 - Altos

Oiapoque - AP. CEP 68980-00

Associate Researcher at the UMR 208 - « Patrimoines Locaux et Gouvernance » PALOC / IRD -

MNHN - Paris-France 